\title{
Future Research in Human Milk
}

\author{
ARMOND S. GOLDMAN AND CUTBERTO GARZA
}

Departments of Pediatrics and Human Biological Chemistry and Genetics. The University of Texas Medical Branch, Galveston, Texas 77550 [A.S.G.] and The Department of Pediatrics, Baylor College of Medicine and The Children's Nutrition Institute, Houston, Texas 77030 [C.G.]

\begin{abstract}
Because of the importance of breast-feeding to child health, research in the formation, composition, and biological effects of human milk should be strongly encouraged. Future exploration should include the processes that are responsible for the synthesis and secretion of human milk; the nature and function of the physical compartments in human milk; the structure and function of certain proteins and other components in human milk; and the in vivo fate and effect of a host of constituents including nutrients, growth factors, hormones, inducers, immunological factors, and antiinflammatory agents. Because of the potential public health benefits, these studies should be a high priority in pediatric research for the next decade. (Pediatr Res 22: 493-496, 1987)
\end{abstract}

Although the survival of the human species until recently has been dependent on breast-feeding, there has been comparatively little scientific interest in human lactation and the composition and biological effects of human milk. Investigators in this field have usually dealt with questions concerning diseases of specific organs, norms of growth and development in nonbreast-fed populations, or the effects of nutrients other than human milk. Furthermore, most studies dealing with the health of infants or with the occurrence or treatment of disorders that are prone to develop during infancy have not examined the effect of breastfeeding as an independent variable.

The situation is, however, changing. In the last few years, three international conferences on human milk have been sponsored by the National Institute of Child Health and Human Development $(1-3)$, proposals regarding this subject have been sought by that institute, and an international society for research in human milk has been formed. Research in breast-feeding is also driven by societal pressures. The major federally sponsored nutrition program targeted at women and young children (WIC) promotes breast-feeding as the optimal feeding. The National Institutes of Health and the United States Department of Agriculture recommend that infants be breast-fed (4). The Surgeon General's Report on Health Promotion and Disease Prevention (5) proposed that the proportion of women who breast-fed their infants be increased, and those objectives are part of the World Health Organization's goal, "Health for All by the Year 2000" (6).

With the advent of new technologies, it has been established that human milk is composed of an array of nutrients (7), enzymes (8), hormones (9), growth factors $(9,10)$, and host defense agents (11), many of which display dynamic changes

Received July 7, 1987; accepted July 13, 1987

Correspondence Armond S. Goldman, M.D., Professor, Division of Immunology and Allergy, Department of Pediatrics, Child Health Center, Room C2-31, The University of Texas Medical Branch, Galveston, TX 77550.

Supported in part by grants from the National Institute of Child Health and Human Development (5 R0I HD 21049-01) and by the U.S. Department of Agriculture (USDA 58-7 MNI-6-100). during lactation and are poorly represented in milks from other species. We are only beginning to unravel the complexities of their formation, fate, and biological actions. In that respect, we will outline some questions that may be worthy to explore at this time.

\section{FORMATION OF HUMAN MILK}

Biochemical mechanisms-maternal factors. Human milk is a unique secretion formed by active synthesis and selective uptake by the mammary gland. In goats, amounts of essential amino acids secreted in milk proteins (12) agree well with their uptake by the mammary gland. Nonessential amino acids are taken up in excess and may provide 20 to $40 \%$ of energy used by the mammary gland. Similar human data are not available, and there are no data to assess the role of amino acid uptake or in situ catabolism in controlling the levels of milk constituents. The secretion of milk proteins appears to be tied closely to a series of membrane "transfers" steps (13). Proteins destined for export move from the endoplasmic reticulum to the Golgi. Modified proteins and other milk constituents contained in secretory vesicles are emptied into the alveolar lumen following their fusion of those vesicles with plasma membranes (14). The levels of most proteins such as lactoferrin peak in colostrum, fall to a nadir in a few months, and then remain stable until the introduction of other foods, whereas the quantitative patterns of other proteins such as lysozyme are more unusual (15). The controls over these events and the substantial interindividual variability in the concentrations of milk proteins are understood poorly.

Endocrine influence on milk protein synthesis in humans also deserve further study. Enzymes associated with the synthesis of lactose, casein, and certain fatty acids develop during the postpartum period when prolactin levels surge and prolactin inhibitors such as progesterone wane (16). In ruminants, growth hormone also controls milk production (17). The mechanisms responsible for increased milk yield and repartitioning of nitrogen are unclear.

After the colostral phase, lactose concentrations remain stable throughout lactation. Lactose synthesis may determine milk volume since this carbohydrate accounts for 60 to $70 \%$ of the osmoles in milk. Lactose biosynthesis is well described (18), but the linkages between genetic and epigenetic factors that determine the rate and absolute synthesis of lactose are not understood. It is unclear if other determinants of milk volume drive lactose synthesis or conversely if factors that influence milk volume do so by first modulating lactose synthesis. Other carbohydrates are found in milk (19), but little is known about their synthetic or secretory mechanisms or their changes during lactation.

Total lipid levels in human milk are more variable than those of lactose or total protein (20) probably because of maternal and dietary factors and differences in sampling techniques. Other factors, however, appear to operate in the control of fatty acids. 
Fatty acids are synthesized de novo in the mammary gland by a multienzyme complex (21). In the rat (22), long chain fatty acids are produced by adipocytes, whereas medium chain fatty acids are made by aveolar cells. The significance of this dichotomy of function is unclear. The secretion of fat is accomplished by formation of milk fat globules. The factors that determine the final concentration of fat have not been identified.

Environmental influences. The specific effects of environmental influences on human lactation remain elusive. Three research aspects are important: the supportive structures that surround the lactating woman, her diet, and environmental contaminants. Lactation does not develop optimally unless there is effective stimulation of the nipple and areola and psychological support for the mother. The production of prolactin, one of the more important effectors of lactation, appears to be activated by serotonin and inhibited by dopamine (23). When the nipple and areola are stimulated, signals are transmitted from the spinothalamic tract to the anterior pituitary via the hypothalamus resulting in prolactin secretion or to the posterior pituitary resulting in oxytocin secretion. By incompletely understood mechanisms, prolactin induces its own receptors, the hypertrophy of secretory cells, and transcription of DNA needed for synthesis of many components of human milk $(24,25)$. Lactation failure can often be traced to factors which impede prolactin or oxytocin secretion. Inadequate oxytocin release may result from ineffective stimulation of the nipple and areola or from adverse physical or psychological situations that augment baseline sympathetic activity (26). Consequently, if the breast is incompletely emptied, alveolar pressure increases, synthesis and secretion of milk decreases, and the mammary gland involutes. The details of these events are important to determine in order to devise means to prevent or curtail lactation failure.

The effects of the maternal diet and environment are also important. Limited data indicate that milk production is conserved despite significant protein-energy malnutrition (27). Less is known concerning the effects of nutritional deprivation upon milk composition. No differences were found among the quantities of SIgA and SIgA antibodies to Escherichia coli somatic antigens in milks of Swedish women, low or high socioeconomic groups in Guatemala, and Ethiopian women at apparent nutritional risk (28). Studies in Gambia detected no differences in milk volume or milk proteins in food supplemented and nonsupplemented groups of women with low food intakes (27). Miranda et al., however, reported lower levels of $\operatorname{IgA}, \operatorname{IgG}$, and $\mathrm{C} 4$ in milk of women in poor nutritional status than in those with normal nutritional indices (29). Given these conflicting results, more studies of the effects of diet on lactation are desirable. The increased intake of certain dietary factors such as trans-fatty acids by lactating women (30) is one of the main issues. The effect of environmental contaminants on maternal health and lactation is of particular concern in view of the drive in third world countries to industrialize despite possible deleterious environmental consequences.

Feedback from the infant. It was anticipated that milk volumes would be related to infant size and growth rate. However, only a small amount of the variance in milk production is explained by those variables. Methodological problems in estimating milk production may be a partial explanation. Hormonal stimuli and possibly physical factors, e.g. blood flow and alveolar pressure that are modulated by the frequency, intensity, and duration of suckling may also play a role. Bursts of prolactin occur with suckling (31), and the increase of this hormone above baseline during suckling has been related to milk volumes. Milk volumes change little after production is established, although baseline prolactin levels are much lower later in lactation (31). The dynamics of prolactin release and the effect of sucking on the delivery of oxytocin and possibly other hormones to the breast suggest a complex communication between mother and infant.

Are biochemical signals transmitted from the infant to mother to modulate the function of the mammary gland? The amounts of certain proteins in human milk ingested by the infant and the synthesis of these same proteins at mucosal sites during early infancy (11) are inversely related, but it is undetermined whether these events are independent or interrelated. The specialized ectoderm of the nipples and areola of the breast may be a recognition-absorption site for factors produced either at the mouth or the oropharynx of the recipient, and this may provide a negative feedback mechanism to decrease the production of the very factors that are made by the infant. One could also envision that cell to cell interactions between the buccal and nipple-areolar epithelium may be involved.

\section{PHYSICAL COMPARTMENTS OF HUMAN MILK}

Human milk is characterized by physical compartments including the fluid phase; milk fat globules and cellular membranes formed by apocrine processes; micelles composed of giant casein molecules; and living cells. Components that are distributed in the nonaqueous compartments include iron and molybdenum in fat globules (32), calcium in casein micelles (32), certain enzymes in fat globules $(8,33)$, and folate-binding proteins in the particulate fraction (34). Compartmentation may be responsible for the increased bioavailability of iron, zinc, and other nutrients in human milk and for the localization of action of certain components. Compartmentation may also shield certain components from digestion until they are required at key sites of the gastrointestinal tract. More studies are needed to examine the pattern of compartmentation during the several phases of lactation, the partition of components in human milk, and the function of the compartments.

\section{COMPOSITION OF HUMAN MILK}

Protein structure and function. The structure and function of certain proteins in human milk have not been ascertained. Undoubtedly, the characterization of these proteins will aid in understanding the effects of human milk on the recipient infant. Indeed, it appears that this exploration will be accelerated by using genes that encode for these proteins. Clues to the function of these novel agents may then be provided by computerized comparisons of their structures to those whose functions are well established.

Carbohydrates. The physiological advantage of lactose as the primary energy source in milk remains unclear. The enzyme that principally degrades lactose, lactase, is low as compared to other disaccharidases in the intestinal tract and those levels of that enzyme are often further diminished during infections and other stresses (35). The principal advantage of lactose may reside in its ability to modulate the infant's intestinal flora. Because of the slow digestion of this disaccharide, significant amounts of the sugar reach the colon in breast-fed infants. The predominate colonic bacteria of the breast-fed infant, Lactobacillus bifidus, use this substrate to produce organic acids that limit the growth of other bacteria (36) and also may compete with binding sites on colonic epithelium for those pathogenic microorganisms.

There are many oligosaccharides in human milk, some of which interfere with the attachment of Escherichia coli, Vibrio cholera, or their enterotoxins (37). The chemistry of these receptor analogues and the function of other oligosaccharide moieties are not completely determined.

\section{EFFECTS ON THE RECIPIENT}

Growth. The daily intake of exclusively breast-fed infants and of older infants who consume human milk and solid foods appear to be significantly below the expected $100 \mathrm{kcal} / \mathrm{kg}$ found in formula fed infants $(38,39)$. Their growth patterns also appear to differ from NCHS standards $(40,41)$ in that they do not appear to maintain their weight or weight for length percentiles over time. These findings should be confirmed in larger populations and various socioeconomic groups. 
The array of nutrients and other special components in human milk may promote a maximal level of metabolic efficiency that is not attained with other foods. Alternatively, apparent differences in intake and possible disparities in growth patterns may be the consequences of the distinct feeding patterns of breast- or bottle-fed infants. Detailed studies of energy expenditure are needed to determine whether differences in energy intake are associated with differences in energy expenditure for basal metabolism, growth, or activity.

Although further methods should be developed, we should capitalize on current techniques such as total body electrical conductivity (42), bioelectrical impedance analysis (43), acoustic plethysmography (44), and stable isotope techniques (45) to assess growth and development in infancy more critically. Potential applications of the dual-labeled water method for measuring total energy expenditure (46) are also exciting. These tools along with classical indirect calorimetry may permit the partitioning of energy expenditure into basal metabolism and the thermic effect of food, growth, and activity.

Changes in fatty acids during early lactation may have functional significance. The proportion of polyunsaturated fatty acids whose carbon chain lengths are less than 20 falls as lactation is established (47). This change may be linked to alterations which occurs in the developing neonatal brain development (48). Rapid cell division in the neonate's brain heightens the need for such fatty acids; as cell division tapers off and myelination increases, the need for monoenoic fatty acids rises. Such nutritional-central nervous system relationships will be important to explore.

Immunological influences. The prevailing view concerning the immunological factors in human milk is that their effects are limited to the alimentary tract and the respiratory system. One objection that has been raised to this assumption is that only small amounts of ingested components such as secretory $\operatorname{lgA}$, lactoferrin, and lysozyme are excreted in the stools of the recipient (49). The fate of the bulk of these factors is thus uncertain. It is unknown whether they are digested in the intestinal tract, adhere to the intestinal mucosa, or are transported into the systemic circulation. These propositions and the possible induction of production of immunological factors in the infant by human milk remain to be explored.

The role of the leukocytes in human milk is also unclarified. Arguments have been advanced that the contribution of these cells to the recipient's immunity is negligible because they would not survive the high acidity of the gastric secretions. That premise does not account for the possibility that the cells may function in sites proximal to the stomach or that the cells may escape the effects of gastric secretions because of the buffering capacity of human milk. Studies are required to further understand the function of these cells. The phagocytes may be able to generate toxic oxygen radicals, but they are not upregulated by chemoattractant agents (50). Furthermore, the neutrophils do not move well in vitro $(50,51)$, whereas the macrophages migrate readily into three-dimensional matrices (51). Perhaps, the two classes of phagocytes in human milk have a dichotomy of function. The neutrophils may be limited to the lumen of the alimentary tract; macrophages may operate in the epithelium. The function of $T$ lymphocytes in human milk is also of interest. Although the relative frequencies of $\mathrm{T}$ cell subpopulations are similar to those in peripheral blood, certain activities attributable to those cells such as cytotoxicity and mitogen-induced proliferation are reduced. Precisely how these cells operate in vivo remains to be established.

Another question concerning the protection afforded by human milk is the lack of clinical manifestations of inflammation during the protective process. There is a paucity of mediators or initiators of inflammation, but a host of antiinflammatory factors (52). The in vivo actions of these antiphlogistic agents should be investigated.

Gastrointestinal development. It is reasonable to ask whether human milk affects the development of the gastrointestinal tract for the following reasons. Much of the surface of the alimentary tract may be exposed to growth factors and hormones from human milk. In that regard, animal experiments demonstrate that colostrum enhances the early growth of intestinal epithelium (53). Finally, differences have been found in the membrane structure of microvilli of the small intestine of newborns and adults $(60)$. Thus, human milk may accelerate the maturation of the gastrointestinal tract of the infant. Studies of the effect of human milk and its constituents on the gastrointestinal tract should be highly productive.

Viral contaminants. Although cytomegalovirus is common in human milk, no disease has associated with its presence (55). Conversely, although there are little data concerning the possibility, there is much apprehension that acquired immunodeficiency may be transmitted by human immunodeficiency viruses in human milk. It is urgent that studies be started to determine the frequency of this virus in human milk, whether breast-feeding per se transmits the infection and what steps should be taken to reduce the risk.

\section{CODA}

There are many unresolved issues concerning human milk including the factors that modulate the formation and secretion of human milk; the limiting nutrients in lactation; the influence of energy expenditure for work and of stress in the workplace and home on lactation; effects of human milk on the infant's body composition, growth, and development; the interplay between the components of human milk and those of the mucosa of the alimentary tract of the recipient; how breast-feeding protects against infections and allergic insults in the infants; the relationships between the biochemical maturation of the infant and the changes that occur in the composition of human milk as lactation proceeds; feedback systems between the infant and the mother; and the effects of weaning on those relationships. Such studies should lead not only to insights concerning the formation and chemistry of human milk, but also to improvements in child health.

\section{REFERENCES}

1. Jensen RG, Neville C 1985 Human Lactation: Milk Components and Methodologies. Plenum Press, New York

2. Hamosh M, Goldman AS 1986 Human Lactation 2: Maternal and Environmental Factors. Plenum Press, New York

3. Goldman AS, Atkinson SA, Hanson LA 1987 Human Lactation 3: Effects of Human Milk upon the Recipient Infant. Plenum Press, New York

4. US Department of Agriculture/US Department of Health and Human Services (USDA/USDHHS) 1980 Nutrition and your health: Dietary guidelines for Americans. US Government Printing Office, Washington, DC

5. US Department of Health and Human Services (USDHHS) 1984 Report of the Surgeon General's Workshop on Breastfeeding and Human Lactation. DHHS Publication no HRS-D-MC 84-2. US Government Printing Office. Washington, DC

6. Mahler H 1980 Hospitals and health for all in the year 2000. Can J Public Health 71:391-394

7. Carlson SE 1985 Human milk nonprotein nitrogen: occurrence and possible functions. In: Barness LA (ed) Advances in Pediatrics. Year Book Medical Publishers, Inc, Chicago, pp 43-70

8. Hamosh M, Freed LM, Jones JB, Berboa SE, Bitman J, Mehta NR, Happ B, Hamosh P 1985 Enzymes in human milk. In: Jensen RG, Neville MC (eds) Human Lactation: Milk Components and Methodologies. Plenum Press, New York, pp 25!-266

9. Koldovsky O, Bedrich A, Pollack P, Rao RK. Thornburg W 1987 Hormones in milk: Their presence and possible physiological significance. In: Goldman AS, Atkinson AS, Hanson LA (eds) Human Lactation 3: Effects of Human Milk Upon the Recipient Infant. Plenum Press, New York, pp 183-196

10. Kidwell WR, Bano M, Burdette K, Lococzy I, Salomon D 1985 Mammary derived growth factors in human milk. In: Jensen RG. Neville MC (eds) Human Lactation: Milk Components and Methodologies. Plenum Press, New York, pp 209-219

11. Goldman AS, Ham Pong AJ, Goldblum RM 1985 Host defenses: Development and maternal contributions. In: Barness LA (ed) Advances in Pediatrics. Yearbook Medical Publishers, Chicago, pp 71-100

12. Mepham TB 1982 Amino acid utilization by lactating mammary gland. J Dairy Sci 65:287-298

13. Keenan TW, Franke WW, Mather IH, Moore DJ 1974 Endomembrane composition and function in milk formation. In: Larson BL (ed) Lactation. 
A Complete Treatise, vol IV. Academic Press, New York, pp 405-443

14. Saacke RG, Heald CW 1974 Cytological aspects of milk formation and secretion. In: Larson BL, Smith VR (eds) Lactation, A Comprehensive Treatise, Vol II. Academic Press, New York, pp 147-189

15. Goldman AS, Garza C, Nichols BL, Goldblum RM 1982 Immunologic factors in human milk during the first year of lactation. J Pediatr 100:563-567

16. Topper YJ and Freeman CS 1980 Multiple hormone interaction in developmental biology of the mammary gland. Physiol Rev 60:1049-1106

17. Bines JA, Hart IC, Morant SV 1980 Endocrine control of energy metabolism in the cow: the effect of milk yield and levels of some blood constituents of injecting growth hormone and growth hormone fragments. Br J Nutr 43:179188

18. Kuhn NJ, Carrick DT, Wilde CJ 1980 Lactose synthesis: the possibilities of regulation. J Dairy Sci 63:328-336

19. Viverge D, Grimmonprez L, Cassanas G, Bardet L, Solere M 1986 Diurnal variations and within the feed in lactose and oligosaccharides of human milk. Ann Nutr Metab 30:196-209

20. Garza C, Butte N 1986 The effect of maternal nutrition on lactational performance. In: Kretchmer N (ed) Frontiers in Clinical Nutrition. Aspen Press, Rockville, MD, pp 15-36

21. Smith S 1980 Mechanism of chain length determination in biosynthesis of milk fatty acids. J Dairy Sci 63:337-352

22. Nolin JM, Thompson BJ, Smith S 1982 Localization of thioesterase II, the chain-length regulatory enzyme of milk fatty acid synthesis, in rat mammary gland epithelial cells. J Endocrinol 94:251-256

23. Tindal JS 1978 Central pathway in oxytocin and prolactin release. In: Yokoyama A, Mizuno $\mathrm{H}$, Nagasawa $\mathrm{H}$ (eds) Physiology of Mammary Glands. University Press, Baltimore, pp 303-322.

24. Barash I, Madar Z, Gertler A 1986 Short-term regulation of prolactin receptors in the liver, mammary gland, and kidney of pregnant and lactating rats infused with ovine prolactin or human growth hormone. Mol Cell Endocrinol 46:235-244

25. Turkington RW, Majumder GC, Kadohama N, Maclndoe JH, Frantz WL 1973 Hormonal regulation of gene expression in mammary cells. Recen Prog Horm Res 29:417-49

26. Cross BA 1955 Neurohormonal mechanisms in emotional inhibition of milk ejection. J Endocrinol 12:29-37

27. Prentice A, Paul AA, Prentice A, Black A, Cole T, Whitehead R 1986 Crosscultural differences in lactation performance. In: Hamosh M, Goldman AS (eds) Human Lactation 2: Maternal and Environmental Factors. Plenum Press, New York, pp 13-44

28. Cruz JR, Carlsson B, Garcia B, Gebre-Medhin M, Hofuander Y, Urrutia JJ, Hanson LA 1982 Studies on human secretory IgA quantity and antibody levels against Escherichia coli in colostrum and milk from underpriviledged and priviledged mothers. Pediatr Res 16:272-276

29. Miranda R, Sarauia NG, Ackerman R, Murphy N, Berman S, McMurray DN 1983 Effect of nutritional status on immunologic substances in human colostrum and milk. Am J Clin Nutr 37:632-640

30. Koletzko B, Mrotzek, Bremer HJ 1987 Trans-fatty acids in human milk and infant plasma and tissue. In: Goldman AS, Atkinson SA, Hanson LA (eds) Human Lactation 3: Effects of Human Milk upon the Recipient Infant Plenum Press, New York, pp 325-335

31. Aono TM, Takenori S, Tsuneo S, Kurachi K 1977 The initiation of human lactation and prolactin response to suckling. J Clin Endocrinol Metab 44:1101-1106

32. Fransson G-B, Lonnerdal B 1984 Iron, copper, zinc, calcium and magnesium in human milk fat. Am $\mathbf{J}$ Clin Nutr 39:185-189

33. Issacs CE 1985 Milk enzyme function: effects of compartmentation and storage conditions on sulfhydrl oxidase and $\gamma$-glutamyl transpeptidase. In: Jensen RG, Neville MC (eds) Human Lactation: Milk Components and Methodologies. Plenum Press, New York, pp 277-282
34. Anthony AC, Utley CS, Marcell PD, Kolhouse JF 1982 Isolation, characterization, and comparison of the solubilized particulate and soluble folate binding proteins from human milk. J Biol Chem 257:10081-10089

35. Lifschitz F 1982 Perspectives of carbohydrate intolerance in infants with diarrhea. In: Fifschitz F (ed) Carbohydrate Intolerance in Infancy. Marcel Dekker, New York, pp 3-12

36. Roberts AK, Van Biervliet JP, Harzer G 1985 Factors of human milk influencing the bacterial flora of infant feces. In: Schaub J (ed) Composition and Physiological Properties of Human Milk. Elsevier, New York, pp 259-270

37. Holmgren J, Svennerholm A-M, Lindblad M, Strecker G 1987 Inhibition of bacterial adhesion and toxin binding by glycoconjugate and oligosaccharide receptor analogues in human milk. In: Goldman AS, Atkinson SA, Hanson LA (eds) Human Lactation 3: The Effects of Human Milk Upon the Recipient Infant. Plenum Press, New York, pp 251-259

38. Butte NF, Garza C, Smith EO, Nichols BL 1984 Human milk intake and growth performance of exclusively breast-fed infants. J Pediatr 104:187-195

39. Stuff J, Garza C, Boutte C, Fraley JK, Smith EO, Klein ER, Nichols BL 1986 Sources of variation in milk and caloric intakes in breast-fed infants: implications for lactation study design and interpretation. Am J Clin Nutr 43:361366

40. Garza C, Stuff J, Butte N, Fraley JK 1987 Growth of the breast-fed infant. In: Goldman AS, Atkinson SA, Hanson LA (eds) Human Lactation 3. The Effects of Human Milk Upon the Recipient Infant. Plenum Press, New York, pp 109-121

41. Whitehead RG 1983 Breastfeeding and Growth. Bull Intern Pediatr Assoc 5:114-129

42. Fiorotto ML, Cochran WJ, Funk RC, Sheng JP, Klish WJ 1987 Total body electrical conductivity measurements: effects of body geometry and composition. Am J Physiol 252:R794-800

43. Solomons NW 1986 How valid are electric impedance measurements in body composition studies? Am J Clin Nutr 44:306-307

44. Deskin WG, Winter DC, Sheng HP, Garza C 1985 Use of a resonating cavity to measure body volume. J Acoust Soc Am 77:756-758

45. Wong WW, Lee LS, Klein PD 1987 Deuterium and oxygen-18 measurements on microliter samples of urine, plasma, saliva, and human milk. Am J Clin Nutr 45:905-913

46. Wong WW, Butte NF, Garza C, Klein PD 1987 Energy expenditure of term infants determined by doubly-labeled water $\left({ }^{2} \mathrm{H}_{2}{ }^{18} \mathrm{O}\right)$ method, indirect calorimetry, and test-weighing. Pediatr Res 21:27A

47. Rodkiewiez B, Hardell LI, Pawlikowska-Rojewska B Tuvemo T 1981 Fatty acid composition of human milk. Upssala J Med Sci 86:279-289

48. Crawford MA, Hall B, Laurance BM, Munhambo A 1976 Milk lipids and their variability. Curr Med Res Opinion 4:33-44

49. Schanler RJ, Goldblum RM, Garza C, Goldman AS 1986 Enhanced fecal excretion of selected immune factors in very low birth weight infants fed fortified human milk. Pediatr Res 20:711-715

50. Thorpe LW, Rudloff HE, Powell LC, Goldman AS 1986 Decreased response of human milk leukocytes to chemoattractant peptides. Pediatr Res 20:373377

51. Ozkaragoz F, Rudloff HE, Rajaraman S, Schmalstieg FC, Goldman AS 1987 Motility of human milk leukocytes in collagen gels. Pediatr Res 21:315A

52. Goldman AS, Thorpe LW, Goldblum RM, Hanson LA 1986 Anti-inflammatory properties of human milk. Acta Paediatr Scand 75:689-695

53. Schwartz SM, Heird WC 1981 Further studies of colostrum-stimulated enteric mucosal growth. Pediatr Res 15:546A

54. Pang KY, Bresson JL, Walker WA 1983 Development of the gastrointestinal mucosal barrier. Evidence for structural difference in microvillus membranes from newborn and adult rabbits. Biochemica Biophysica Acta 727:201-208

55. Pass RF 1987 Viral Contamination of Milk. In: Goldman AS, Atkinson SA, Hanson LA Human Lactation 3: The Effects of Human Milk Upon the Recipient Infant. Plenum Press, New York, pp 279-287 